\title{
Women of Faith and Religious Identity in Fin-de-Siècle France. By Emily Machen.
}

Syracuse, New York: Syracuse University Press, 2019. 240pp.

In the context of intensive, government-led reforms to promote secularization (laïcité) in late nineteenth-century France, religious leaders confronted the challenge of converting unbelievers and boosting the numbers of regular worshippers in churches and synagogues. Proselytization was carried out by women and men of Catholic and Protestant faiths. Jews, although they did not proselytize, were concerned nonetheless about the survival of French Judaism, which depended on families' active commitment to practice Jewish law at home.

The goal of Emily Machen's study is to reveal the ways in which gender shaped the methods employed by women as they sought to expand their spiritual mission and reinvigorate French communities of believers. Machen builds upon previous studies that have focussed either on Catholic, or on Protestant, or on Jewish efforts in religious-based programs of social and charitable action in the France of the Third Republic. Her contribution is to compare and contrast women's activities across all three faiths, teasing out the consequences that female religious leadership could have for male religious engagement.

Machen's evidence is drawn mostly from the publications of religious organizations, supplemented by some unpublished archival materials such as police records. She uses this range of primary sources to analyze the debates about gendered roles within communities of believers, as well as to explore the ways in which female religious activism was portrayed to wider audiences. 
Like other scholars, Machen regards the longstanding tradition of charitable work undertaken by lay women and nuns as preparing the way for greater societal acceptance of women's professional competence and women's entry into 'masculine' career paths. Her findings show that, while historians have often argued for a 'feminization' of religion in nineteenth-century France, there was a parallel phenomenon of 'masculinization' for the women who took on enormous responsibilities and developed public profiles through presidencies and representation on voluntary committees, editorial activities, fundraising, speech-making and media campaigns.

Within Catholic communities, for example, Machen highlights the language adopted in the press and at conferences that described Catholic women as militant warriors and apostles who could 'save France'. Some Protestants questioned strict adherence to the Apostle Paul's message that forbade women from teaching men and speaking in church; instead they looked for alternative biblical models that provided a rationale in support of public ministries for women. Jews were unwilling to make women rabbis; however, just as Protestants debated the exclusion of women from pastorships, so too Jewish discusssions were taking place on the subject of whether women could be counted as part of the quorum (minyan) of ten people needed for public prayers.

As Machen points out, the publications produced by religious organizations are useful for understanding the public images associated with faith that each organization sought to promote in order to attract people into churches and synagogues. The mix of conservative attitudes on gender with currents that were more progressive was manifest in diverse settings and rhetoric across Catholic, Protestant and Jewish communities. Machen's book should stimulate historians to undertake further research on the private side of the theological and 
social evolution she traces for the France of the Third Republic. We need more scholarly work on how individual women and men experienced personal tensions in pursuing religious activities and what they thought privately about the dissonant messages and models presented by religious leaders in an increasingly secular world.

Elizabeth C. Macknight

University of Aberdeen

Aberdeen, Scotland 